\title{
Interspecies and intraspecies transmission of triple reassortant H3N2 influenza A viruses
}

\author{
Hadi M Yassine ${ }^{1}$, Mohammad Q Al-Natour ${ }^{2}$, Chang-Won Lee ${ }^{1}$ and \\ Yehia M Saif*1
}

\begin{abstract}
Address: ${ }^{1}$ Food Animal Health Research Program, Ohio Agricultural Research and Development Center, The Ohio State University, Wooster OH, USA and ${ }^{2}$ Department of Pathology and Animal Health, Faculty of Veterinary Medicine, Jordan University of Science and Technology, Irbid, Jordan

Email: Hadi M Yassine - yassine.2@osu.edu; Mohammad Q Al-Natour - mqalnatour@yahoo.com; Chang-Won Lee - lee.2854@osu.edu; Yehia M Saif* - saif.1@osu.edu

* Corresponding author
\end{abstract}

Published: 28 November 2007

Virology Journal 2007, 4:129 doi:10.1 186/1743-422X-4-129

This article is available from: http://www.virologyj.com/content/4/I/I29

(C) 2007 Yassine et al; licensee BioMed Central Ltd.

This is an Open Access article distributed under the terms of the Creative Commons Attribution License (http://creativecommons.org/licenses/by/2.0), which permits unrestricted use, distribution, and reproduction in any medium, provided the original work is properly cited.
Received: 24 September 2007

Accepted: 28 November 2007

\begin{abstract}
I. Abstract
The triple reassortant $\mathrm{H} 3 \mathrm{~N} 2$ viruses were isolated for the first time from pigs in 1998 and are known to be endemic in swine and turkey populations in the United States. In 2004, we isolated two H3N2 triple reassortant viruses from two turkey breeder flocks in Ohio and Illinois. Infected hens showed no clinical signs, but experienced a complete cessation of egg production. In this study, we evaluated three triple reassortant $\mathrm{H} 3 \mathrm{~N} 2$ isolates of turkey origin and one isolate of swine origin for their transmission between swine and turkeys. Although all 4 viruses tested share high genetic similarity in all 8 genes, only the Ohio strain (A/turkey/Ohio/3/3053/04) was shown to transmit efficiently both ways between swine and turkeys. One isolate, A/turkey/North Carolina/ 03, was able to transmit from pigs to turkeys but not vice versa. Neither of the other two viruses transmitted either way. Sequence analysis of the HAI gene of the Ohio strain showed one amino acid change ( $D$ to $A$ ) at residue 190 of the receptor binding domain upon transmission from turkeys to pigs. The Ohio virus was then tested for intraspecies transmission in three different avian species. The virus was shown to replicate and transmit among turkeys, replicate but does not transmit among chickens, and did not replicate in ducks. Identifying viruses with varying inter- and intra-species transmission potential should be useful for further studies on the molecular basis of interspecies transmission.
\end{abstract}

\section{Introduction}

Influenza A viruses are highly contagious pathogens that have been isolated form a wide variety of animals, including man, birds, swine, horses, minks, seals, whales, and most recently from cats and dogs [1-3]. Influenza A viruses are rarely known to cross species barriers [4,5], however, their interspecies transmission has always been a major concern. Although determinants of interspecies transmission are still not fully identified, many studies showed that the compatibility between the hemagglutinin (HA) protein of the virus and its corresponding receptor on the host cell is essential for establishing an infection in a specific host [6-8]. Pigs are known to be a major reservoir for $\mathrm{H} 1 \mathrm{~N} 1$ and $\mathrm{H} 3 \mathrm{~N} 2$ influenza viruses and have been hypothesized to act as intermediate host for interspecies transmission of influenza A viruses $[6,9,10]$. Turkeys on the other hand, are susceptible to a wide range of influenza A viruses and serve as an important host for these 
viruses [11,12]. Influenza infections in turkeys range from asymptomatic to severe disease, including respiratory tract disorder, depression, drop in eggs production and high mortality [11]. Between 1978 and 1981, our laboratory was the first to report on experimental and natural infections of turkeys with H1N1 swine influenza viruses $[13,14]$.

In 1998, a new lineage of swine influenza viruses, triple reassortants (TR) H3N2, were isolated for the first time from pigs in the United States (U.S.) [15]. These viruses had genes derived from human (HA, NA, and PB1), Swine (NP, M, and NS) and avian viruses (PA and PB2) $[16,17]$. The H3N2 TR viruses are now endemic in swine populations in North America [17,18]. In 2003 and 2004, similar viruses (H3N2 TR) were isolated from turkeys in two different locations in the U.S. $[19,20]$. Later in the same year, we isolated another H3N2 TR virus from turkey breeder hens in Illinois that were vaccinated twice with a swine H3N2 TR virus. Infected turkeys experienced complete cessation of egg production, but had no other clinical signs. In a previous study (manuscript submitted) we observed major antigenic differences between turkey and swine H3N2 TR viruses. The antigenic relatedness (Rvalue) between the turkey viruses and the swine virus (vaccine strain) was less than $30 \%$ as expressed by the Archetti and Horsfall formula [21] based on hemagglutinin inhibition (HI) and virus neutralization (VN) tests. At least eight amino acid changes were observed at the antigenic sites of the HA1 molecule between the turkey viruses and the swine vaccine virus. Although the transmission of H3N2 TR viruses from pigs to turkeys was suggested in previous reports $[19,20]$, no experimental work has been done to support this premise. Hence, we initiated this study to evaluate the interspecies transmission of these viruses between swine and turkeys, and to determine at the molecular level the basis for such transmission. Additionally, we tested one strain, A/turkey/Ohio/313053/04, that was shown to transmit between swine and turkeys for its intraspecies transmission in turkeys, chickens and ducks. Identifying viruses with different transmission potential between swine and turkeys will help in identifying the molecular determinants that control such transmission using the reverse genetics techniques.

\section{Results}

\section{I Interspecies transmission of H3N2 influenza viruses from pigs to turkeys}

Three H3N2 influenza isolates of turkey origin and one $\mathrm{H} 3 \mathrm{~N} 2$ influenza isolate of swine origin were evaluated for their transmission from pigs to turkeys. Additionally, two H1N1 isolates of swine and turkey origins were included for comparison. All viruses were shown to replicate in pigs but with different efficiencies (Table 1). The A/turkey/ Ohio/313053/04 and A/turkey/North Carolina/03 viruses replicated more efficiently than the other H3N2 viruses, with nasal swab titer of $2 \times 10^{6}$ and $2 \times 10^{6.6} 50 \%$ tissue culture infectious dose $\left(\mathrm{TCID}_{50}\right)$ per $\mathrm{ml}$, respectively (Table 1). The H1N1 turkey strain, A/turkey/Ohio/ 88 , showed the highest replication titer $\left(2 \times 10^{8.1} \mathrm{TCID}_{50} /\right.$ $\mathrm{ml}$ ) among all viruses tested. The Ohio strain, A/turkey/ Ohio/313053/04, elicited the highest antibody titer (1:360 HI) among all the H3N2 viruses tested (Table 1). Different patterns of transmission from pigs to turkeys were observed among the H3N2 TR viruses (Table 2). The H3N2 Ohio strain was transmitted from pigs to turkeys and virus was detected for more than two days in turkeys using the real-time reverse-transcription PCR (RRT-PCR). Four out of the eight contact turkeys got infected and three of them seroconverted to an average HI titer of 1:80. The

Table I: Interspecies transmission of H3N2 and HINI influenza viruses from pigs to turkeys; virus detection in inoculated pigs

\begin{tabular}{|c|c|c|c|c|c|c|c|c|}
\hline Virus & $\begin{array}{c}\text { No. } \\
\text { positives I } \\
\text { to } 3 \text { DPI* }\end{array}$ & $\begin{array}{l}\text { No. } \\
\text { positives } \\
4 \text { to } 6 \text { DPI }\end{array}$ & $\begin{array}{l}\text { No.positives } \\
\text { for } 2 \text { or } \\
\text { more days }\end{array}$ & $\begin{array}{l}\text { Peak day } \\
\text { of virus } \\
\text { detection }\end{array}$ & $\begin{array}{c}\text { Estimated } \\
\text { average virus titer } \\
\text { on peak day/ml }\end{array}$ & $\begin{array}{l}\text { No. of animals } \\
\text { seroconverted/ } \\
\text { total inoculated }\end{array}$ & $\begin{array}{c}\text { HI**** } \\
\text { average titer } \\
\text { at I4 DPI }\end{array}$ & $\begin{array}{c}\text { Virus } \\
\text { isolation } \\
\text { from swab } \\
\text { samples }\end{array}$ \\
\hline $\begin{array}{c}\text { A/TK/IL/04 } \\
\text { (H3N2) }\end{array}$ & $5 / 5 * *$ & $3 / 3 * * * *$ & $5 / 5$ & 4DPI & $2 \times 10^{4.5}$ & $3 / 3$ & $1: 160$ & Positive \\
\hline $\begin{array}{c}\text { A/TK/OH/04 } \\
\text { (H3N2) }\end{array}$ & $5 / 5$ & $4 / 4 * * *$ & $5 / 5$ & 5DPI & $2 \times 10^{6.0}$ & $4 / 4$ & $1: 360$ & Positive \\
\hline $\begin{array}{c}\text { A/TK/NC/03 } \\
\text { (H3N2) }\end{array}$ & $5 / 5$ & $4 / 4 * * *$ & $5 / 5$ & 4DPI & $2 \times 10^{6.6}$ & $4 / 4$ & $\mathrm{I}: 220$ & Positive \\
\hline $\begin{array}{l}\text { A/SW/NCl } \\
03 \text { (H3N2) }\end{array}$ & $5 / 5$ & $3 / 3 * * *$ & $5 / 5$ & 4DPI & $2 \times 10^{4.7}$ & $3 / 4$ & $\mathrm{I}: 340$ & Positive \\
\hline $\begin{array}{c}\text { A/TK/OH/88 } \\
(\mathrm{HINI})\end{array}$ & $5 / 5$ & $4 / 4 * * *$ & $5 / 5$ & 4DPI & $2 \times 10^{8.1}$ & $4 / 4$ & $\mathrm{I}: 320$ & NT \\
\hline $\begin{array}{l}\text { A/SWIOH/ } \\
06 \text { (HINI) }\end{array}$ & $5 / 5$ & $4 / 4 * * *$ & $5 / 5$ & 4DPI & $2 \times 10^{5.6}$ & $4 / 4$ & $1: 160$ & NT \\
\hline
\end{tabular}

* Days post inoculation. Swabs were collected on daily bases and results are displayed in three days intervals.

** No. of pigs positive with RRT-PCR/No. of pigs inoculated.

*** Some pigs were euthanized at 3 DPI to collect organs and tissues for other studies.

***** Hemagglutinin inhibition.

NT Not Tested 
Table 2: Interspecies transmission of $\mathrm{H} 3 \mathrm{~N} 2$ and $\mathrm{HINI}$ influenza viruses from pigs to turkeys; virus detection in turkeys in contact with inoculated pigs

\begin{tabular}{|c|c|c|c|c|c|c|c|c|c|}
\hline Virus & $\begin{array}{c}\text { No. } \\
\text { positives I } \\
\text { to } 3 \text { DPE* }\end{array}$ & $\begin{array}{c}\text { No. } \\
\text { positives } 4 \\
\text { to } 6 \mathrm{DPE}\end{array}$ & $\begin{array}{c}\text { No. } \\
\text { positives } 7 \\
\text { to } 9 \mathrm{DPE}\end{array}$ & $\begin{array}{l}\text { No. } \\
\text { positives } \\
\text { for } 2 \text { or } \\
\text { more days }\end{array}$ & $\begin{array}{l}\text { Peak day } \\
\text { of virus } \\
\text { detection }\end{array}$ & $\begin{array}{c}\text { Estimated } \\
\text { average } \\
\text { virus titer on } \\
\text { peak day/ml }\end{array}$ & $\begin{array}{l}\text { No. of animals } \\
\text { seroconverted } \\
\text { /total exposed }\end{array}$ & $\begin{array}{c}\text { HI*** } \\
\text { average } \\
\text { titer at } \\
\text { I } 4 \text { DPE }\end{array}$ & $\begin{array}{c}\text { Virus } \\
\text { isolation from } \\
\text { swab samples }\end{array}$ \\
\hline $\begin{array}{c}\text { A/TK/IL/04 } \\
\text { (H3N2) }\end{array}$ & $3 / 8 * *$ & $0 / 8$ & $0 / 8$ & $0 / 8$ & 2DPE & $2 \times 10^{3}$ & $0 / 8$ & - & Negative \\
\hline $\begin{array}{l}\text { A/TK/OH/ } \\
04 \text { (H3N2) }\end{array}$ & $0 / 8$ & $4 / 8$ & $2 / 8$ & $3 / 8$ & 6DPE & $2 \times 10^{3.12}$ & $3 / 8$ & $1: 80$ & Positive \\
\hline $\begin{array}{l}\text { A/TK/NCl } \\
03 \text { (H3N2) }\end{array}$ & $0 / 8$ & $2 / 8$ & $1 / 8$ & $1 / 8$ & 5DPE & $2 \times 10^{3.8}$ & $0 / 8$ & - & Positive \\
\hline $\begin{array}{l}\text { A/SW/NCl } \\
03 \text { (H3N2) }\end{array}$ & $4 / 8$ & $0 / 8$ & $0 / 8$ & $0 / 8$ & 2DPE & $2 \times 10^{3}$ & $0 / 8$ & - & Negative \\
\hline $\begin{array}{l}\text { A/TK/OH/ } \\
88 \text { (HINI) }\end{array}$ & $0 / 8$ & $0 / 8$ & $0 / 8$ & - & - & - & - & - & NT \\
\hline $\begin{array}{l}\text { A/SWIOH/ } \\
06 \text { (HINI) }\end{array}$ & $0 / 8$ & $0 / 8$ & $0 / 8$ & - & - & - & - & - & NT \\
\hline
\end{tabular}

* Days post exposure. Swabs were collected on daily bases and results are displayed in three days intervals.

** No. of turkeys positive with RRT-PCR/total No. of contact turkeys.

*** Hemagglutinin inhibition.

NT Not Tested

A/turkey/North Carolina/03 virus was detected in three out of eight contact turkeys using the RRT-PCR, with one turkey detected positive for two days; however, none of the infected turkeys seroconverted. Viruses were successfully re-isolated using Madin-Darby Canine Kidney (MDCK) cells from the contact turkeys infected with $\mathrm{A} /$ turkey/Ohio/313053/04 and A/turkey/North Carolina/03 H3N2 viruses. On the other hand, although three out of eight and four out of eight swab samples were AIV-positive with RRT-PCR at two days post exposure (DPE) from turkeys in contact with pigs infected with A/turkey/Illinois/04 and A/swine/North Carolina/03, respectively, no viruses were isolated from any of the RRT-PCR positive samples and none of the turkeys seroconverted (Table 2). Both H1N1 viruses replicated in pigs, but none of them were detected in the contact turkeys as determined by RRT-PCR and HI tests.

\subsection{Interspecies transmission of H3N2 influenza viruses from turkeys to pigs}

We also evaluated the transmission of the H3N2 viruses from turkeys to pigs (Tables 3 and 4). As expected, all $\mathrm{H} 3 \mathrm{~N} 2$ viruses replicated in turkeys regardless of their isolation origin and were detected in the inoculated turkeys for at least six days, except for the A/swine/North Caroilina/03 virus that was detected for only four days. In general, the swab viral titers were lower than that from pigs, ranging from $2 \times 10^{2.8}$ to $2 \times 10^{3.3} \mathrm{TCID}_{50} / \mathrm{ml}$. Again, the Ohio and North Carolina turkey isolates replicated at the highest titers of $2 \times 10^{3.3} \mathrm{TCID}_{50} / \mathrm{ml}$. All viruses were shown to elicit antibody response in turkeys with the highest titer observed against the Ohio strain at 1:420 HI. Only the Ohio strain transmitted from the infected turkeys to the contact pigs as determined by RRT-PCR, HI test and virus isolation (Table 4). The first positive pig was detected at the $3 \mathrm{DPE}$, and the rest became positive at 5

Table 3: Interspecies transmission of $\mathrm{H} 3 \mathrm{~N} 2$ influenza viruses from turkeys to pigs; virus detection in inoculated turkeys

\begin{tabular}{|c|c|c|c|c|c|c|c|c|c|}
\hline Virus & $\begin{array}{c}\text { No. } \\
\text { positives I } \\
\text { to } 3 \text { DPI* }\end{array}$ & $\begin{array}{c}\text { No. } \\
\text { positives } \\
4 \text { to } 6 \text { DPI }\end{array}$ & $\begin{array}{c}\text { No. } \\
\text { positives } \\
7 \text { to } 9 \text { DPI }\end{array}$ & $\begin{array}{l}\text { No. } \\
\text { positives } \\
\text { for } 2 \text { or } \\
\text { more days }\end{array}$ & $\begin{array}{l}\text { Peak day } \\
\text { of virus } \\
\text { detection }\end{array}$ & $\begin{array}{c}\text { Estimated } \\
\text { average } \\
\text { virus titer on } \\
\text { peak day/ml }\end{array}$ & $\begin{array}{c}\text { No. of animals } \\
\text { seroconverted } \\
\text { /total } \\
\text { inoculated }\end{array}$ & $\begin{array}{c}\text { HI**** } \\
\text { average } \\
\text { titer at } \\
\text { I4DPI }\end{array}$ & $\begin{array}{c}\text { Virus } \\
\text { isolation from } \\
\text { swab samples }\end{array}$ \\
\hline $\begin{array}{c}\text { A/TK/IL/04 } \\
\text { (H3N2) }\end{array}$ & $6 / 10 * *$ & $7 / 10$ & NT & $8 / 10$ & 5DPI & $2 \times 102.9$ & $9 / 10$ & $\mathrm{I}: 300$ & Positive \\
\hline $\begin{array}{l}\text { A/TK/OH/ } \\
04 \text { (H3N2) }\end{array}$ & $7 / 10$ & $5 / 10$ & $2 / 10$ & $8 / 10$ & 4DPI & $2 \times 10^{3.3}$ & $4 / 6$ & I:420 & Positive \\
\hline $\begin{array}{l}\text { A/TK/NCl } \\
03(\mathrm{H} 3 \mathrm{~N} 2)\end{array}$ & $6 / 10$ & $6 / 10$ & NT & $6 / 10$ & 4DPI & $2 \times 103.3$ & $3 / 10$ & $\mathrm{I}: 80$ & Positive \\
\hline $\begin{array}{l}\text { A/SW/NCl } \\
03 \text { (H3N2) }\end{array}$ & $4 / 10$ & $1 / 10$ & $0 / 10$ & $3 / 10$ & 3DPI & $2 \times 10^{2.8}$ & $2 / 10$ & I:80 & Positive \\
\hline
\end{tabular}

* Days post inoculation. Swabs were collected on daily bases and results are displayed in three days intervals.

** No. of turkeys positive with RRT-PCR/No. of inoculated turkeys.

**** Hemagglutinin inhibition.

NT Not Tested 
Table 4: Interspecies transmission of H3N2 influenza viruses from turkeys to pigs; virus detection in pigs in contact with inoculated turkeys

\begin{tabular}{|c|c|c|c|c|c|c|c|c|c|}
\hline Virus & $\begin{array}{c}\text { No. } \\
\text { positives I } \\
\text { to } 3 \text { DPE* }\end{array}$ & $\begin{array}{c}\text { No. } \\
\text { positives } 4 \\
\text { to } 6 \mathrm{DPE}\end{array}$ & $\begin{array}{c}\text { No. } \\
\text { positives } 7 \\
\text { to } 9 \mathrm{DPE}\end{array}$ & $\begin{array}{l}\text { No. positives } \\
\text { for } 2 \text { or } \\
\text { more days }\end{array}$ & $\begin{array}{l}\text { Peak day } \\
\text { of virus } \\
\text { detection }\end{array}$ & $\begin{array}{c}\text { Estimated } \\
\text { average } \\
\text { virus titer on } \\
\text { peak day/ml }\end{array}$ & $\begin{array}{c}\text { No. of animals } \\
\text { seroconverte } \\
\text { d/total } \\
\text { exposed }\end{array}$ & $\begin{array}{c}\text { HI*** } \\
\text { average } \\
\text { titer at } \\
\text { I4DPI }\end{array}$ & $\begin{array}{c}\text { Virus } \\
\text { isolation } \\
\text { from swab } \\
\text { samples }\end{array}$ \\
\hline $\begin{array}{c}\text { A/TK/IL/04 } \\
\text { (H3N2) }\end{array}$ & $0 / 5^{* *}$ & $0 / 5$ & $0 / 5$ & $0 / 5$ & - & - & $0 / 5$ & - & - \\
\hline $\begin{array}{l}\text { A/TK/OH/ } \\
04 \text { (H3N2) }\end{array}$ & $1 / 5$ & $5 / 5$ & $5 / 5$ & $5 / 5$ & 5DPE & $2 \times 10^{5}$ & $5 / 5$ & I:320 & Positive \\
\hline $\begin{array}{l}\text { A/TK/NCl } \\
03(\text { H3N2) }\end{array}$ & $0 / 5$ & $0 / 5$ & $0 / 5$ & $0 / 5$ & - & - & $0 / 5$ & - & - \\
\hline $\begin{array}{l}\text { A/SW/NCl } \\
03 \text { (H3N2) }\end{array}$ & $0 / 5$ & $0 / 5$ & $0 / 5$ & $0 / 5$ & - & - & $0 / 5$ & - & - \\
\hline
\end{tabular}

* Days post exposure. Swabs were collected on daily bases and results are displayed in three days intervals.

** No. of pigs positive with RRT-PCR/total No. of contact pigs.

**** Hemagglutinin inhibition

DPE. All pigs infected with the Ohio strain seroconverted with an average HI titer of 1:320.

\subsection{Sequence analysis}

The two surface glycoproteins encoding genes, HA and NA, were amplified and sequenced from A/turkey/Ohio/ 313053/04 H3N2 virus isolated from directly inoculated pigs, pigs in contact with infected turkeys, directly inoculated turkeys and turkeys in contact with infected pigs. Pairwise sequence alignment showed two changes in the HA gene sequence upon replication and transmission of the virus from pigs and turkeys. The first change was observed at residue 190 (D to A) of the receptor binding domain (RBD) in viruses isolated from pigs in contact with infected turkeys (Figure 1). The other change was observed at residue 246 ( $\mathrm{S}$ to $\mathrm{N}$ ) in two of the inoculated pigs and one of the turkeys in contact with inoculated pigs (Figure 1). No changes were observed in the NA gene upon replication and transmission of the virus from pigs to turkeys and vise versa.

\subsection{Intraspecies transmission of A/turkey/Ohio/3 / 3053/04 H3N2 virus in turkeys, chickens and ducks}

To evaluate the transmission potential of $\mathrm{H} 3 \mathrm{~N} 2$ viruses in different avian species, we tested the intraspecies transmission of $\mathrm{A} /$ turkey/Ohio/313053/04 virus (strain that showed efficient transmission between pigs and turkeys) in turkeys, chickens and ducks (Table 5). The virus behaved differently in different avian species, where it was capable of replication in turkeys and chickens, but not in ducks. Although the replication titers in chickens were higher than those in turkeys, $2 \times 10^{6}$ and $2 \times 10^{3.4}$ TCID $_{50} /$ $\mathrm{ml}$, respectively, no transmission was detected among chickens. The virus was detected for more than one day in $90 \%$ of the inoculated chickens, of which $62 \%$ seroconverted to an average titer of 1:216 HI. On the other hand, $80 \%$ of the inoculated turkeys were positive with RRTPCR for influenza virus for more than two days, and all of them seroconverted to an average HI titer of 1:990. The very high HI average titer of the turkey serum was due to two turkeys that showed an HI titer of 5120 and 2560 respectively. Nine of the ten contact turkeys in the same cage became positive, two of which were positive at 3 DPE, while the rest were positive between 7 DPE and 9 DPE. Only two of the contact turkeys seroconverted to an HI titer of 1:120 HI units. The delay in infection in most of the contact turkeys would explain the negative HI tests (only two of the contact turkeys were positive) that were performed on serum samples collected at 14 day post exposure (DPE).

\section{Discussion}

Generally, influenza A viruses are considered host specific, nevertheless, some can overcome the species barrier and infect a new host. The mechanisms by which the influenza A viruses cross the species barriers and the molecular determinants that control such transmission are not well identified. Pigs have been hypothesized to play a role in interspecies transmission by acting as "mixing vessel" for the generation of reassortant viruses that might have the potential to jump from one species to another [22,23]. In 1998, a new lineage of swine viruses, H3N2 TR, emerged and caused influenza like illnesses in pig populations in the U.S. $[15,16]$. Similar viruses were later isolated from turkey breeder hens experiencing drop in eggs production and it was hypothesized that these viruses were transmitted from pigs to turkeys $[19,20]$.

Our findings indicated the ability of certain H3N2 TR viruses to transmit between pigs and turkeys. Despite the high degree of molecular similarity between some of these viruses, like $\mathrm{A} /$ turkey/Illinois/04 and A/turkey/Ohio/ 313053/04 (>99\% similarity in all genes), they behaved differently in the transmission experiments, with the A/ turkey/Ohio/313053/04 transmitting both ways between 


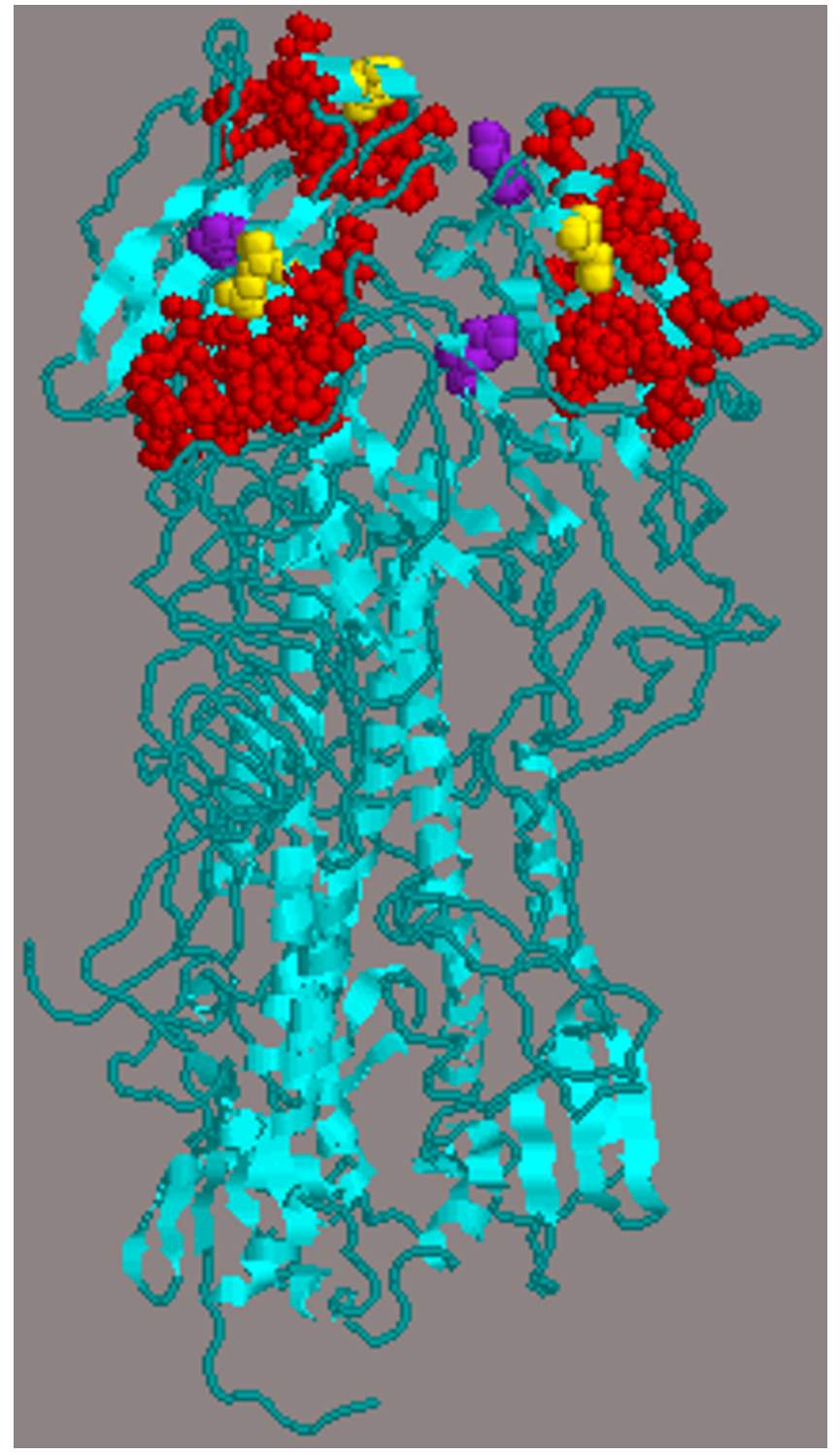

Figure I

Cartoon representing the amino acid changes at the HA molecule of the $\mathrm{A} /$ turkey/Ohio/3 I3053/04 H3N2 virus, that occurred upon replication and transmission of the virus between turkeys and pigs. Red: receptor binding domain (RBD). Yellow: the change at residue 190 that occurred upon transmission of the virus from turkeys to pigs. Violet: the change at residue 246 that occured in two of the inoculated pigs and one of the contact turkeys with inoculated pigs.

the two species and the A/turkey/Illinois/04 virus not transmitting either way.

Regardless of the differences in transmission, all viruses were capable of replication in turkeys and pigs but to different titers. Furthermore, the A/turkey/Ohio/313053/04, the strain transmissible between pigs and turkeys, was shown to infect and transmit among turkeys, infect but did not transmit among chickens, and did not infect ducks.

We speculate that the H3N2 TR viruses, which have the HA gene from human lineage viruses, retain the receptor binding specificity to NeuAca2,6Gal receptors similar to human influenza viruses. Val226 and Ser228 were expressed in the HA1 molecules of both turkey and swine triple reassortants, while Leu/Ile226 and Ser228 are usually expressed in the human viruses [24]. Leu, Ile, and Val are neutral non-polar amino acids, and substitutions between them most likely maintain the hydrophobic interactions and the proper conformation at the binding domain [25]. Gln226 and Gly228 are usually found in the HA1 molecules of avian viruses amino acids at these positions and are known to play a critical role in determining the receptor binding specificity [25]. Our unpublished work demonstrated the presence of substantial amount of NeuAca 2,6Gal receptors in turkey tracheas, which would explain the ability of these viruses to replicate in turkeys as well as in pigs that are known to express these receptors [6]. Although ducks were shown to express few NeuAca2,6Gal receptors in their tracheas (unpublished work), the A/turkey/Ohio/313053/04 H3N2 virus was not able to replicate in ducks. The absence of a large number of NeuAc 2 2,6Gal receptors in ducks' tracheas may explain the inability of the A/turkey/Ohio/313053/ $04 \mathrm{H} 3 \mathrm{~N} 2$ virus to replicate in ducks. However, there may be factors other than receptors distribution that contribute to host tropism of influenza viruses and more work is needed in this area.

While all viruses had the Asp (D) amino acid at residue 190 of the receptor binding domain (RBD), a D to A (Ala) change occurred upon the transmission of the A/turkey/ Ohio/313053/04 virus from turkeys to pigs. The presence of either D (specific for SA 2,6- gal) or E (specific for SA 2 2,3-gal) at amino acid position 190 of the HA molecule in the H3 subtypes was reported in previous studies $[26,27]$, however, our observation of (A) residue at this position is the first of its kind to our knowledge (sequencing was performed on the HA gene of the Ohio virus isolated from three different pigs in contact with infected turkeys). The role of (A) residue at position 190 in determining receptor binding specificity should be further investigated. In addition, the role of Asn $(\mathrm{N})$ residue at position 246 of the HA molecule is not known and will be further studied in out laboratory.

Although all viruses were shed by pigs for more than 6 days, the A/turkey/Ohio/313053/04 and A/turkey/North Carolina/03 viruses replicated to higher titers than A/turkey/Illinois/04 and A/swine/North Carolina/03 viruses. This might be one of the possible reasons that allowed A/ 
Table 5: Intraspecies transmission of A/TK/OH/3 I3053/04 (H3N2) Influenza virus in chickens, ducks and turkeys

\begin{tabular}{|c|c|c|c|c|c|c|c|c|}
\hline $\begin{array}{c}\text { Virus TK/ } \\
\text { OH/04 } \\
\text { (H3N2) }\end{array}$ & $\begin{array}{l}\text { No. positive I } \\
\text { to } 3 \text { DPI/DPE }\end{array}$ & $\begin{array}{l}\text { No. positive } 4 \\
\text { to } 6 \text { DPI/DPE }\end{array}$ & $\begin{array}{l}\text { No. positive } 7 \\
\text { to } 9 \text { DPI/DPE }\end{array}$ & $\begin{array}{l}\text { No. positive I0 } \\
\text { to I } 2 \text { DPI/DPE }\end{array}$ & $\begin{array}{l}\text { Peak day } \\
\text { of virus } \\
\text { detection }\end{array}$ & $\begin{array}{c}\text { Estimated } \\
\text { average virus } \\
\text { titer on peak } \\
\text { day/mL }\end{array}$ & $\begin{array}{l}\text { No. of animals } \\
\text { seroconverted } / \\
\text { total exposed }\end{array}$ & $\begin{array}{c}\mathrm{HI} \\
\text { average } \\
\text { titer }\end{array}$ \\
\hline $\begin{array}{l}\text { Infected } \\
\text { chickens }\end{array}$ & $19 / 20$ & $10 / 16^{*}$ & NT & NT & 2DPI & $2 \times 10^{6}$ & $10 / 16$ & $1: 216$ \\
\hline $\begin{array}{l}\text { Contact } \\
\text { chickens }\end{array}$ & $0 / 10$ & $0 / 10$ & $0 / 10$ & NT & - & - & $0 / 10$ & - \\
\hline $\begin{array}{l}\text { Infected } \\
\text { ducks }\end{array}$ & $0 / 15$ & $0 / 15$ & $0 / 15$ & NT & - & - & $0 / 15$ & - \\
\hline $\begin{array}{c}\text { Contact } \\
\text { ducks }\end{array}$ & $0 / 15$ & $0 / 15$ & $0 / 15$ & NT & - & - & $0 / 15$ & - \\
\hline $\begin{array}{l}\text { Infected } \\
\text { turkeys }\end{array}$ & $13 / 15$ & $8 / 10^{*}$ & NT & NT & 3DPI & $2 \times 10^{3.4}$ & $10 / 10$ & $\mathrm{I}: 990$ \\
\hline $\begin{array}{l}\text { Contact } \\
\text { turkeys }\end{array}$ & $2 / 10$ & $2 / 10$ & $6 / 10$ & $7 / 10$ DPI & 8DPE & $2 \times 10^{3.5}$ & $2 / 10$ & $1: 120$ \\
\hline
\end{tabular}

* Some of the inoculated turkeys and chickens were euthanized at 3DPI to collect tracheas for other studie

turkey/Ohio/313053/04 and A/turkey/North Carolina/03 viruses to transmit from pigs to turkeys (all animals were inoculated with the same virus titer). The A/turkey/Illinois/04 and $\mathrm{A} /$ swine/North Carolina/03 viruses were detected only on one day in contact turkeys by RRT-PCR, however, no viruses were obtained upon isolation attempts. The high sensitivity of the RRT-PCR might explain the ability to detect these viruses in contact turkeys, whereas the viruses were inefficient in replicating to a high titer in turkeys. In contrast, the A/turkey/Ohio/ 1988 H1N1 virus was shown to replicate to a very high titer in pigs $\left(10^{7.1} \mathrm{TCID}_{50}\right)$, but it did not transmit to turkeys. The above observations indicate the specificity of individual influenza A viruses, even within the same subtype (H3N2 TR in this case), in their ability to transmit between species.

Previous analysis of the A/swine/North Carolina/03 virus in our laboratory showed that it has a 13 amino acids stalk deletion in the NA protein (manuscript submitted). Shortened NA stalks might result in less efficient virus release, and hence lower virus titers $[28,29]$. This might explain our results from pigs and turkeys. However, the exact effect of NA stalk deletion is not clear because many chicken adapted H5, H7, and H9 viruses show different length stalk deletions and replicate to very high titer in poultry [30-32].

The identification of viruses with varying potential for interspecies transmission should be useful for reverse genetic studies to identify the gene(s) and the amino acid(s) residues that contribute to the transmission of these viruses between swine and turkeys. The use of the reverse genetics and site directed mutagenesis could also be helpful in deciphering the role of residues 190 and 246 of the HA molecule in receptor binding specificity and transmission of these viruses between swine and turkeys.
Interspecies transmission studies between swine (mammalian) and turkeys (avian) will enhance our understanding of the genetic factors that control transmission of influenza viruses and would help in improvement of surveillance strategies for early detection of influenza A viruses.

\section{Materials and methods 5.I Viruses}

Four H3N2 TR viruses of turkey or swine origin were included in this study. Additionally, two H1N1 viruses (one turkey origin and one swine origin) were included for comparison. Two H3N2 turkey viruses, A/turkey/Illinois/04 and A/turkey/Ohio/313053/04, were isolated in MDCK cells in our laboratory in 2004, and were propagated in 9-10 days old embryonated chicken eggs (ECE) to make working stocks. One turkey virus, $\mathrm{A} /$ turkey/North Carolina/03 (H3N2) (passaged twice (P2) in MDCK cells), and one swine virus, $\mathrm{A} /$ swine/North Carolina/03 (H3N2) (unknown passage number), were kindly provided by Dr. Eric Gonder (Goldsboro Milling Co. Goldsboro, NC), and were propagated in 9-10 days old ECE to make working stocks. The turkey H1N1 (A/turkey/Ohio/ 1988) and swine H1N1 (A/swine/Ohio/06) viruses were isolated in ECE in our lab in 1988 and 2006, respectively. Both viruses were propagated once in ECE to make working stocks. The two H1N1 influenza viruses were included as controls for the transmission from pig to turkey, but not in the turkey to pig transmission study.

\subsection{Virus isolation}

Turkey tracheal swabs were used for inoculation of MDCK cell line maintained in Opti-MEM minimum essential medium (Invitrogen, Grand Island, NY) containing 0.5 $\mu \mathrm{g} / \mathrm{ml}$ trypsin. The samples were passaged twice in MDCK cells and then used to inoculate 9-10 days old specific pathogen free (SPF) ECE to make working stocks. 


\subsection{Transmission studies}

A schematic layout of the room used for the transmission studies is presented in Figure 2. The rooms were mechanically ventilated and the air was HEPA filtered at the intake and the exhaust. Briefly, the infected and contact animals were placed close to each other in two different cages (with rubber coated floors) to study the indirect transmission of $\mathrm{H} 3 \mathrm{~N} 2 \mathrm{TR}$ viruses between swine (large white breed) and specific pathogen free (SPF) turkeys. The direction of the air current was always from the infected animals' side to the contact animals' side. The animals received a virus titer of $10^{7}$ TCID50 contained in $0.5 \mathrm{ml}$, and the contact animals were placed in the same room close to the infected animals at one day post inoculation (1 DPI). Nasal swabs from pigs and tracheal swabs from turkeys were collected on daily basis and were maintained in Brain Heart Infusion (BHI) media and were directly used for RNA extractions. Contact animals were always handled first.

Intraspecies transmission experiments with the Ohio virus (A/turkey/Ohio/313053/04) were performed in SPF turkeys, SPF chickens and commercial pekin ducks. The individual bird ( $\mathrm{n}=15$ for turkeys and ducks, and $\mathrm{n}=20$ for chickens) received a virus titer of $10^{7}$ TCID50 contained in $0.5 \mathrm{ml}$, and the contact animals (10 turkeys, 10 chickens and 15 ducks) animals were placed in the same cage at 1 DPI. Tracheal swabs were collected on daily basis and were maintained in BHI media and were directly used to do RNA extractions. Non-inoculated negative control animals were placed in a separate room and were treated like infected animals.

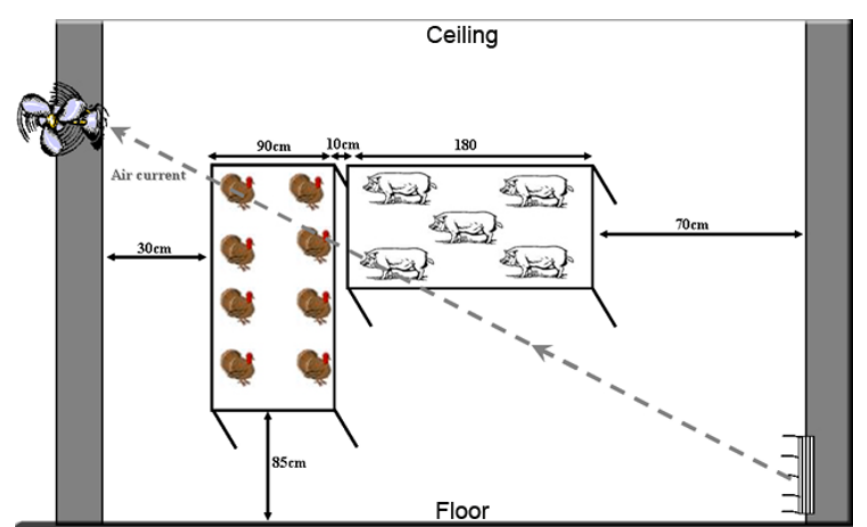

Figure 2

Schematic of the room used in the study of interspecies transmission of influenza viruses (swine to turkey transmission setting in this case). The air flowed from the experimentally infected animals to the contact uninfected animals. Scale is not proportional.

\subsection{Antisera collection and $\mathrm{HI}$ test}

Blood was collected from all animals at zero and fourteen days post inoculation/exposure (DPI/DPE) to test for antibodies to $\mathrm{H} 3 \mathrm{~N} 2$ and $\mathrm{H} 1 \mathrm{~N} 1$ influenza viruses. Sera were harvested and inactivated at $56^{\circ} \mathrm{C}$ for $30 \mathrm{~min}$ before being used in hemagglutinin inhibition (HI) test. The HI test was carried out as previously described [33]. Titers were determined by using twofold serial dilutions of antisera $(25 \mu \mathrm{l}), 4 \mathrm{HA} / 25 \mu \mathrm{l}$ units of homologous antigen and a $0.5 \%$ suspension of turkey erythrocyte per test well.

\subsection{RNA extraction and real-time RT-PCR}

RNA extraction and RRT-PCR reactions were performed as previously described [34-36]. Briefly, swab samples in 1.5 $\mathrm{ml} \mathrm{BHI}$ media were vortexed for 5 seconds then left standing for $15 \mathrm{~min}$ to precipitate the debris. Of the $1.5 \mathrm{ml}$ swab sample, $300 \mu \mathrm{l}$ were used for RNA extraction using the RNeasy kit (Qiagen, Valencia, CA). RRT-PCR was performed in $25 \mu \mathrm{l}$ reaction volume using the Qiagen onestep RT-PCR kit with the following conditions: $10 \mathrm{pmol}$ of each primer, $320 \mu \mathrm{M}$ each dNTP, $0.12 \mu \mathrm{M}$ FAM labeled probe, 13 units RNase inhibitor, $1 \mu$ l enzyme mix, $8 \mu \mathrm{l}$ of RNA sample, and water was added to get a total volume of $25 \mu$. The RRT-PCR conditions were: $50^{\circ} \mathrm{C}$ for $30 \mathrm{~min}$, $95^{\circ} \mathrm{C}$ for $15 \mathrm{~min}$, and 45 cycles of $1 \mathrm{sec}$ at $94^{\circ} \mathrm{C}$ and 20 sec at $60^{\circ} \mathrm{C}$. Reactions were run in the Cephid Smartcycler thermocycler (Utech Products, Inc.; Schenectady, NY 12305).

\subsection{Standard curve for virus titer estimation}

To estimate the virus titer in the infected animals, we established a standard curve based on one turkey and one swine H3N2 viruses of known TCID $_{50}$ titer. Briefly, RNA was extracted from A/turkey/Illinois/04 and A/swine/ North Carolina/03 and serial dilutions were prepared. The serially diluted RNA was used to run the RRT-PCR as described above and a standard curve was established.

5.7 Sequence analysis and molecular graphic visualization The HA1 and NA genes of the A/turkey/Ohio/313053/04 virus were amplified from viruses obtained from directly inoculated pigs, pigs in contact with infected turkeys, directly inoculated turkeys and turkeys in contact with infected pigs. Both genes were amplified with standard reverse transcription (RT) PCR using influenza specific primers and the one-step RT-PCR kit (Qiagen) following the manufacturer instructions. The RT-PCR products were separated by electrophoresis on $1 \%$ agarose gel, and amplicons of the right size were excised from the gel and purified with Qiaquick gel extraction kit (Qiagen). Sequencing was done at the Ohio Agricultural Research and Development Center (OARDC) sequencing facility using the ABI Prism 3100 automated sequencing machine (Applied Biosystems, Foster City, CA 94404). Pairwise sequence alignments were performed in the MegAlign 
program (DNASTAR, Madison, Wis.) to determine nucleotides and amino acids sequences similarity. Amino acid changes in the HA protein of different isolates were located using the Rasmol software (v2.6.4) (Biomolecular Structures Group, Hertfordshire, UK) on the HA structure of H3 subtype influenza virus, A/Aichi/2/68, (1HGG) downloaded from the Protein Data Bank website $[37,38]$.

\section{Acknowledgements}

The authors are grateful to Dr. Eric Gonder for providing two of the strains used in this study. We would also like to thank Mr. Robert Dearth and Mr. Abul Rauf for their help in animal work. This study was partially supported by funds from USDA, CSREES, AI-CAP project.

\section{References}

I. Webster RG, Bean WJ, Gorman OT, Chambers TM, Kawaoka Y: Evolution and ecology of influenza $\mathbf{A}$ viruses. Microbiol Rev 1992, 56(I): I52-179.

2. Songserm T, Amonsin A, Jam-on R, Sae-Heng N, Pariyothorn N, Payungporn $S$, Theamboonlers $A$, Chutinimitkul $S$, Thanawongnuwech $R$ Poovorawan Y: Fatal avian influenza A H5NI in a dog. Emerg Infect Dis 2006, I 2(I I): I744- 1747.

3. Songsermn T, Amonsin A, Jam-on R, Sae-Heng N, Meemak N, Pariyothorn N, Payungporn S, Theamboonlers A, Poovorawan Y: Avian influenza $\mathrm{H} 5 \mathrm{NI}$ in naturally infected domestic cat. Emerg Infect Dis 2006, I 2(4):68I-683.

4. Murphy BR, Sly DL, Tierney EL, Hosier NT, Massicot JG, London WT, Chanock RM, Webster RG, Hinshaw VS: Reassortant virus derived from avian and human influenza $A$ viruses is attenuated and immunogenic in monkeys. Science 1982 218(4579): 1330-1332.

5. Beare AS, Webster RG: Replication of avian influenza viruses in humans. Arch Virol 1991, I I 9(I-2):37-42.

6. Ito T, Couceiro JN, Kelm S, Baum LG, Krauss S, Castrucci MR, Donatelli I, Kida H, Paulson JC, Webster RG, Kawaoka Y: Molecular basis for the generation in pigs of influenza $A$ viruses with pandemic potential. J Virol 1998, 72(9):7367-7373.

7. Ito $\mathrm{T}$ : Interspecies transmission and receptor recognition of influenza A viruses. Microbiol Immunol 2000, 44(6):423-430.

8. Ito T, Kawaoka Y: Host-range barrier of influenza A viruses. Vet Microbiol 2000, 74(I-2):7I-75.

9. Campitelli L, Donatelli I, Foni E, Castrucci MR, Fabiani C, Kawaoka $Y$, Krauss S, Webster RG: Continued evolution of HINI and H3N2 influenza viruses in pigs in Italy. Virology 1997, 232(2):310-318.

10. Scholtissek C V.S. Hinshaw, and C.W. Olsen: Influenza in pigs and their role as intermediate host. In Textbook of Influenza Edited by: K.G. Nicholson RGWAJH. Oxford United Kingdom , Blackwell Science; 1998:137-| 45

II. Swayne DE, King DJ: Avian influenza and Newcastle disease. J Am Vet Med Assoc 2003, 222(II):I534-I540.

12. Suarez DL, Woolcock PR, Bermudez AJ, Senne DA: Isolation from turkey breeder hens of a reassortant HIN2 influenza virus with swine, human, and avian lineage genes. Avian Dis 2002, 46(I): ||$|-| 2 \mid$

13. Mohan R, Saif YM, Erickson GA, Gustafson GA, Easterday BC: Serologic and epidemiologic evidence of infection in turkeys with an agent related to the swine influenza virus. Avian Dis 1981, 25(I): II-16.

14. S YM: Experimental infection of turkeys with swine influenza A virus. 1978, I:938-943.

15. Zhou NN, Senne DA, Landgraf JS, Swenson SL, Erickson G, Rossow K, Liu L, Yoon K, Krauss S, Webster RG: Genetic reassortment of avian, swine, and human influenza $A$ viruses in American pigs. J Virol I999, 73( I 0):885I-8856.

16. Karasin AI, Schutten MM, Cooper LA, Smith CB, Subbarao K, Anderson GA, Carman S, Olsen CW: Genetic characterization of H3N2 influenza viruses isolated from pigs in North America, 1977-1 999: evidence for wholly human and reassortant virus genotypes. Virus Res 2000, 68(I):7I-85.
17. Webby RJ, Swenson SL, Krauss SL, Gerrish PJ, Goyal SM, Webster RG: Evolution of swine $\mathrm{H} 3 \mathrm{~N} 2$ influenza viruses in the United States. J Virol 2000, 74( I 8):8243-825I.

18. Olsen CW, Karasin Al, Carman S, Li Y, Bastien N, Ojkic D, Alves D, Charbonneau G, Henning BM, Low DE, Burton L, Broukhanski G: Triple reassortant H3N2 influenza A viruses, Canada, 2005. Emerg Infect Dis 2006, I 2(7): I I32-I I 35.

19. Choi YK, Lee JH, Erickson G, Goyal SM, Joo HS, Webster RG, Webby $\mathrm{RJ}$ : H3N2 influenza virus transmission from swine to turkeys, United States. Emerg Infect Dis 2004, I ( ( 2):2 I 56-2 I60.

20. Tang Y, Lee CW, Zhang Y, Senne DA, Dearth R, Byrum B, Perez DR, Suarez DL, Saif YM: Isolation and characterization of H3N2 influenza A virus from turkeys. Avian Dis 2005, 49(2):207-213.

21. Archetti I, Horsfall FL Jr.: Persistent antigenic variation of influenza A viruses after incomplete neutralization in ovo with heterologous immune serum. J Exp Med 1950, 92(5):44I-462.

22. Castrucci MR, Donatelli I, Sidoli L, Barigazzi G, Kawaoka Y, Webster RG: Genetic reassortment between avian and human influenza A viruses in Italian pigs. Virology 1993, I93(I):503-506.

23. Kida H, Ito T, Yasuda J, Shimizu Y, Itakura C, Shortridge KF, Kawaoka Y, Webster RG: Potential for transmission of avian influenza viruses to pigs. J Gen Virol 1994, 75 ( Pt 9):2183-2188.

24. Lindstrom S, Sugita S, Endo A, Ishida M, Huang P, Xi SH, Nerome K Evolutionary characterization of recent human H3N2 influenza $A$ isolates from Japan and China: novel changes in the receptor binding domain. Arch Virol 1996, I4 I (7): I349-I 355.

25. Vines A, Wells K, Matrosovich M, Castrucci MR, Ito T, Kawaoka Y: The role of influenza A virus hemagglutinin residues 226 and 228 in receptor specificity and host range restriction. J Virol 1998, 72(9):7626-7631.

26. Matrosovich M, Tuzikov A, Bovin N, Gambaryan A, Klimov A Castrucci MR, Donatelli I, Kawaoka Y: Early alterations of the receptor-binding properties of $\mathrm{HI}, \mathrm{H2}$, and $\mathrm{H3}$ avian influenza virus hemagglutinins after their introduction into mammals. J Virol 2000, 74( I 8):8502-85 I2.

27. Nobusawa $E$, Ishihara $H$, Morishita $T$, Sato K, Nakajima K: Change in receptor-binding specificity of recent human influenza $A$ viruses (H3N2): a single amino acid change in hemagglutinin altered its recognition of sialyloligosaccharides. Virology 2000 , 278(2):587-596.

28. Els MC, Air GM, Murti KG, Webster RG, Laver WG: An 18-amino acid deletion in an influenza neuraminidase. Virology 1985 , I 42(2):24I-247.

29. Luo G, Chung J, Palese P: Alterations of the stalk of the influenza virus neuraminidase: deletions and insertions. Virus Res 1993 29(2): $|4|-\mid 53$

30. Lee CW, Swayne DE, Linares JA, Senne DA, Suarez DL: H5N2 avian influenza outbreak in Texas in 2004: the first highly pathogenic strain in the United States in $\mathbf{2 0}$ years? J Virol 2005, 79(I7): I|4|2-||42|

31. Spackman E, Senne DA, Davison S, Suarez DL: Sequence analysis of recent $\mathrm{H} 7$ avian influenza viruses associated with three different outbreaks in commercial poultry in the United States. J Virol 2003, 77(24): 13399-13402.

32. Abolnik C, Bisschop SP, Gerdes GH, Olivier AJ, Horner RF: Phylogenetic analysis of low-pathogenicity avian influenza H6N2 viruses from chicken outbreaks (200I-2005) suggest that they are reassortants of historic ostrich low-pathogenicity avian influenza H9N2 and H6N8 viruses. Avian Dis 2007, 5 I ( I Suppl):279-284.

33. Beard CW: Serological procedures. In A laboratory manual for the isolation and identification of avian pathotypes Edited by: $\mathrm{H}$. G. Purchase LHACHDJEP. Dubuque, lowa, Kendall-Hunt Publishing; 1989:192-200.

34. Lee CW, Suarez DL: Application of real-time RT-PCR for the quantitation and competitive replication study of $\mathrm{H} 5$ and $\mathrm{H} 7$ subtype avian influenza virus. I Virol Methods 2004, II 9(2): $15 \mid-158$.

35. Spackman E, Senne DA, Bulaga LL, Myers TJ, Perdue ML, Garber LP, Lohman K, Daum LT, Suarez DL: Development of real-time RT. PCR for the detection of avian influenza virus. Avian Dis 2003, 47(3 Suppl): I079-1082.

36. Spackman E, Senne DA, Myers TJ, Bulaga LL, Garber LP, Perdue ML, Lohman K, Daum LT, Suarez DL: Development of a real-time reverse transcriptase PCR assay for type $A$ influenza virus 
and the avian $\mathrm{H} 5$ and $\mathrm{H} 7$ hemagglutinin subtypes. J Clin Microbiol 2002, 40(9):3256-3260.

37. Sauter NK, Hanson JE, Glick GD, Brown JH, Crowther RL, Park SJ, Skehel J], Wiley DC: Binding of influenza virus hemagglutinin to analogs of its cell-surface receptor, sialic acid: analysis by proton nuclear magnetic resonance spectroscopy and $X$-ray crystallography. Biochemistry 1992, 3 I (40):9609-962I.

38. [http://www.rcsb.org/pdb/home/home.do].

Publish with Biomed Central and every scientist can read your work free of charge

"BioMed Central will be the most significant development for disseminating the results of biomedical research in our lifetime. " Sir Paul Nurse, Cancer Research UK

Your research papers will be:

- available free of charge to the entire biomedical community

- peer reviewed and published immediately upon acceptance

- cited in PubMed and archived on PubMed Central

- yours - you keep the copyright

Submit your manuscript here:

http://www.biomedcentral.com/info/publishing_adv.asp 